The Reality of Distance Social Work Education in the Arab World during Coronavirus (COVID-19) Pandemic

$$
\text { واقع تعليم الخدمة الاجتماعية عن بعد في العالم العربي }
$$

في ظل جائحة كورونا (كوفيد - 9 (1)

\author{
by \\ Mohamed Moustafa Mohamed Shahin \\ of Social Work, Benha.

$$
\begin{aligned}
& \text { إعداد } \\
& \text { د/ محمد مصطفى محمد شاهين } \\
& \text { أستاذ مساعد بقسم خدمة الغرد } \\
& \text { بالمعهد العالي للخدمة الاجتماعية ببنها }
\end{aligned}
$$

Associate Professor of Social Casework at the Higher Institute 


\title{
The Reality of Distance Social Work Education in the Arab World during Coronavirus (COVID-19) Pandemic
}

\begin{abstract}
This study sought to describe and analyze the reality of Distance Social Work Education in the Arab World during COVID-19 Pandemic through identifying social work faculty members' attitudes towards this system, their perceptions on the degree of its achievement of Social Work Education objectives, the most important obstacles it faces in addition to investigating the relationship between each variable and some demographic characteristics of the study sample. So, this study is a descriptive, analytical one and it used the social survey approach. The sample consisted of 248 of social work faculty members in Egypt, Saudi Arabia and Jordan. It used an electronic questionnaire form as a primary tool for collection data from the sample individuals.
\end{abstract}

The study results indicated faculty members has negative attitudes towards Distance Social Work Education and this educational system cannot achieve almost all Social Work Education objectives both wholly and partially. Also the results determined the obstacles faced by it and limit its competence to reach the hoped outcomes by Social Work Education in general. Also the statistical analysis indicated there are statistically significant differences between each variable and variables of age and experience (yrs) among study sample.

According to these results the study concluded the current Distance Social Work System is not consistent with the interactive human nature of Social Work Profession which in turn makes the educational process at risk in case COVID -19 Pandemic continues and we are forced to adopt it the years ahead.

Keywords: Faculty members' attitudes - Social Work Education - Distance Education-COVID 19 Pandemic. 


\section{واقع تعليم الخدمة الاجتماعية عند بعد في العالم العربي \\ في ظل جائحة كورونا (كوفيد ـ 9 (1)}

\section{ملخص الاراسة}

سعت هذه الدراسة إلى رصد وتحليل واقع نظام تعليم الخدمة الاجتماعية عن بعد في العالم

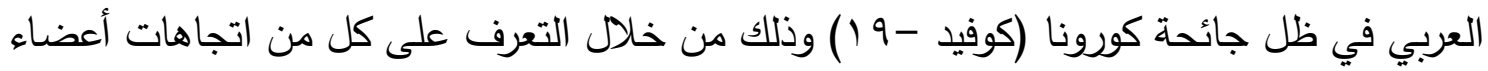
هيئة تدريس الخدمة الاجتماعية نحو هذا النظام التعليمي ، وتصوراتهم نحو درجة تحقيقه لأهداف تعليم الخدمة الاجتماعية ، وأهم المعوقات التي يواجهها ، بجانب الوقوف على لثلى طبيعة العلاقة بين كل متغير من تلك المتغيرات وبعض الخصائص الديموغرافية لعينة الدراسة ، وعليه فقد اندرجت الدراسة ضمن أنماط الدراسات الوصفية التحليلية واعتمدت على منهرج المستج الاجتماعي بالعينة والتي بلغت قوامها (248) عضو هيئة تدريس من العاملين في كليات ومعاهد وبرامج الخمة الاجتماعية في كل من مصر والسعودية والأردن ، واعتمدت على استمارة استبيان الكترونية كأداة

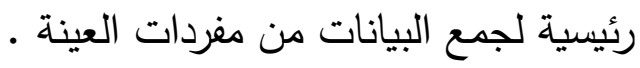

وقد أسفرت نتائج الدراسة عن وجود اتجاهات سلبية لدى أعضاء هيئة التدريس نحو نظام تعليم الخدمة الاجتماعية عن بعد، وعدم تمكن هذا النظام التعليمي من تحقيق غالبية أهداف تعليم الخدمة

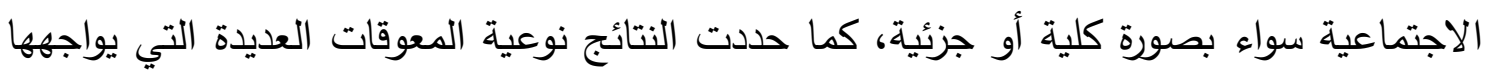

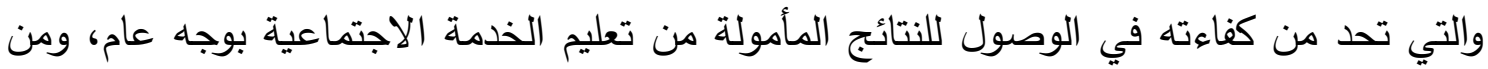
أبرز النتائج أيضاً التي اظهرها التحيل الإحصائي وجود فروق ذات دلاتلاتلة إحصائية بين كل متغير من المتغيرات السابقة ومتغيري السن وعدد وسنوات الخبرة لدى عينة الدراسة

وبناء على تلك النتائج فقد خلصت الدراسة بشكل عام إلى أن نظام التعليم عن بعد بصورته

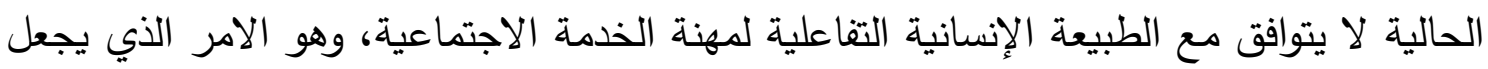

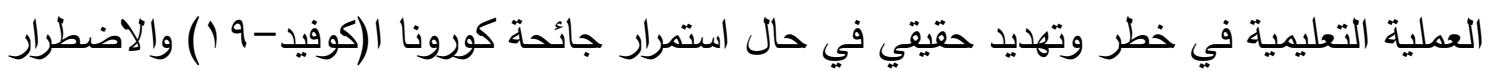
إلى الاخذ بهذا النظام في السنوات القادمة فئه

الكلمات المفتاحية: اتجاهات أعضاء هيئة التدريس - تعليم الخدمة الاجتماعية - التعليم عن بعد

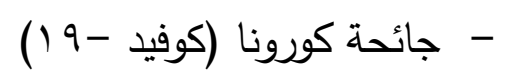




\section{Introduction.}

The continuous and rapid technological developments have led Educational Institutions to reconsider their programs and their existing educational systems, seek to take actual moves to create modern educational systems and methods that keep up with those technological developments and satisfy various needs of learners and teachers. This led to the so-called Distance Education as a modern system which has become a main element and an important component of educational system today.

The importance of Distance Education lies in its endeavour to solve the problem of knowledge explosion, increase admission opportunities in education, especially in Higher Education, break psychological barriers between learners and teachers, and satisfy various needs of the learners; in addition to the application of the principle of equal opportunities in education by means of providing equal access to education to the vulnerable and disadvantaged students that cannot access the Formal Education. (Demirbilek, M., 2019.23). furthermore, distance education system contributes to eliminating geographic and regional barriers between learners and teachers, and developing their knowledge and own skills via the use of communication and information technology

The Arab world was among these newly emerging countries in online learning and distance education in general. Its beginnings go back to 1979 as a recommendation of a conference held in Jordan with the participation of specialists and experts from UNESCO as a call to provide educational opportunities for Arab students who are unable to enroll in traditional universities (Al-Sharhan, 2014,44). Some Universities and Secondary Education Institutions in some Arab Countries have already responded to technological development and accredited Distance Education into their Educational Systems.

However, online learning is still facing many problems in the Arab world that have formed obstacles and challenges represented in the, human obstacles such as the scarcity of professors who are proficient in the practice of electronic education and systemic constraints associated with 
the lack of conviction of the decision-makers in this type of education (AlMuhaisen, 2003,46-47) In addition, several studies have also confirmed the complexity of changing the idea of switching from traditional education to online learning for teachers and the lack of capabilities to start an online learning project Consequently, technical challenges, unqualified infrastructure, and lack of knowledge among students and faculty members have remained among the most important obstacles to effective online learning in university education in the Arab countries (Barakat, 2012; Abdulaziz \& Muhammad, 2012)

The Arab League Educational, Cultural, and Scientific Organization (ALECSO), based on its studies in the Arab region on the use of information technology in the educational system, indicated a difference in the willingness to apply technology in education online learning. This difference and disparity are due to the unqualified technological infrastructure, the lack of open educational resources, and the gap between the development of accessible educational materials and their actual use. Consequently, the Arab world lacks a clear vision or policy to implement technology in the educational system (Jemni, M., \& Khribi, M, 2017,73).

In another recent study included all Arab countries in determining the gap of open educational resources for distance education in the Arab world. The results showed no balance in the progress of open educational resources and the failure of many Arab countries to use and apply open educational resources, whether in universities and institutes or schools. In other words, the use and approval of open educational resources in the educational system are still in its infancy in all Arab countries (Tlili et al., 2020).

Naturally, the above-mentioned situation applies to Social Work Discipline as all Social Sciences in which the vast majority of them have not introduced Distance Education before nor they have begun to apply it actually except when COVID -19 broke-out. Some proponents of Distance Social Work Education indicate that it may contribute to reduce a lot of burdens that are put on Faculties and Institutes of Social Work as coping with the steady rise in student's numbers, facing lack of faculty members 
and diminishing the cost of the educational process in addition to facilitating education opportunities among Social Work students whose conditions curb their admission into regular education as in cases of health problems

Also some researchers indicate Online and Distance Social Work Education has become a reality and the current technological developments some scientific disciplines responded to stress the necessity of applying this system by Social Work Departments and Programs in various universities today because of the possibility of benefiting from its various techniques in developing and modernizing Social Work Education in a way that contributes to promote the level of professional practice. (Kurzman, P. \& Littlefield, M.,2020,11)

In contrast, others believe Social Work Students who receive Distance Education face a lot of difficulties and obstacles that prevent the full benefit of this system versus in-class Social Work. Therefore, there are still fears among faculty members and those who are responsible for Social Work Education concerning the inability of this system to satisfy all educational needs of the students (Zidan, 2015, 228). Besides, it is necessary to create an educational environment in which it is reduced negative feelings such as fear, anxiety, anger, and an increase in positive emotions during the education process. However, high touches are needed in social work education to avoid the mechanical reaction environment in high tech (high tech and high touch) learning environments (Tuncay, T., 2020,22-21).

Anyway, some researchers investigated Distance Social Work Education from different perspectives especially after incorporating it mainly in the educational process in the light of COVID-19 Pandemic. These studies, either before or after the pandemic, attempted to make clear the general components and bases of this type of education, its models, the significant differences between it and in-class education, whether or not it is appropriate for Social Work Education or its effectiveness in achieving objectives and outcomes related to Social Work Education and methods of its development. 
For instance, a study by Oliaro, L. \& Trotter, C. (2010) sought to explore the significant differences between In-Class Social Work Education (at the university ) and Distance Social Work Education (outside the university ) and was conducted on a group of new graduates who had a bachelor degree in Social Work from Monash University. The study concluded the new graduates who used Distance Education were less satisfied about Education System compared to their counterparts who used In-Class Education. Also it stressed Distance Social Work Education System satisfies the needs of a very limited group of students.

Concerning Distance Education Models used in Social Work Education a study by East, J et. al. (2014) sought to identify the most important and effective models especially that are used in postgraduate studies programs. In this regard the study examined 121 directors' opinions about this system and concluded Web-based technology is the most common model. It recommended the cooperation between Social Work Education Experts to innovate other more effective models of Distance Social Work Education. A study by Levin et. al.(2018) stressed faculty members' attitudes towards Distance Social Work Education System and the extent of their satisfaction about it determine the extent of its success or failure. Therefore, the study sught to identify the attitudes of 376 faculty members towards online learning in social work and their perceptions of effectiveness. The study concluded the participants had fears and negative attitudes towards online learning in social work. In addition, the vast majority of the participants stressed this system is less than on - the ground education in helping the students to achieve Objectives and competences expected by Social Work. A study by Al Nagar, Atef (2019) concentrated on Distance Social Work Education characteristics, justifications of using it in the Egyptian Society, the needed equipment to apply it in the best way in addition to determining the most important Distance Social Work Education Methods from the perspective of Generalist Practice in Social Work. Also the study identified the suggested roles of the Social Worker at Departments of students Counselling and Youth Care in helping Social Work Students to benefit fully from the Educational Process in the light of Distance Education System. 
Concerning technological means and techniques that can be used in Distance Social Work Education, a study by Said, Gomana (2020) aimed at identifying the student's attitudes towards applying technology in Social Work Education in the light of COVID-19 Pandemic. The study concluded the students affirmed the necessity of applying technology in the educational process, faculty members has to have a group of skills to achieve the maximum benefit from using that technology. The study provided some suggestions to develop using technology in Social Work Education during COVID-19 crisis. Also a study by Kourgiantakis, T. \& Eunjung L. (2020) asserted COVID-19 Pandemic has led to radical changes in Social Work Education Systems after the forced, sudden transfer of InClass education to Distance Education - the study concluded, after asking the experts opinions, that distance social work education can be effective if faculty members consider time, workload, organization and curriculum.

In that regard a study by Dinh, L, Nguyen, T.(2020) asserted social work students and teachers in Vitnam faced a lot challenges and obstacles during the sudden transfer from in-class education to online education as a result of COVID-19 pandemic because most social work syllabi require the direct interaction between the teacher and the students. Consequently, the study unveiled the student's satisfaction level about the direct interaction was greatly higher than that of online education. Also the study asserted the necessity of using a long - term strategy to improve and develop online social work education.

By reviewing literature, in short, it appeared there was no consensus between the researchers concerning the application of distance social work education, its effectiveness and its suitability for the nature of social work education. When looking at $A$ to studies that dealt with social work education before the Corona pandemic, we find that some defend the traditional education system, and others who support the integration of technology and distance education by using electronic tools.

Considering the studies that reflected the reality created by COVID-19 crisis and its effect on the educational process in social work, it can be said that distance social work education in social work has become something 
that cannot be ignored. Nevertheless, it should be taking into account appropriate standards that maintain the quality of social work education. As training on distance education, whether for social work faculty members or students, should be a future priority in the social work profession's history.

On the other hand, there is still limited literature and studies about distance social work education in the Arab World in general either before or after COVID-19 crisis. This led the researcher to conduct this study that aimed at investigating intentionally and directly the reality of this educational system during COVID-19 crisis that exists until now through identifying social work faculty members' attitudes towards this new system, outlining its degree of achievement of social work education objectives, unveiling the obstacles of using it as perceived by faculty members.

\section{Study Problem:}

Distance social work education is still a controversial issue among the researchers and those who are interested in social work education. Quality of social work education is often questionable (Crisp, B.,2018, 718). In other words, there is still doubt among some researchers about the benefit and effectiveness of this system in reaching the expected objectives though the reality asserts the technological development has contributed greatly in improving quality of teaching and also in spite of the existence of increasing evidence about the effectiveness and the success of this educational system in university teaching in other subjects

Irrespective of contrasting opinions about using of distance social work education, all faculties, institutes and programs of social work in the world and in the Arab countries were forced to apply this system in the light of COVID-19 pandemic after they were unable to continue the in -class social work education or the so-called the ground education. Due to the fact that the distance education system is recently established in these faculties and educational institutions, on the one hand; and because of the fundamental changes that have occurred in the components of the social work education system, on the other hand, the present study attempted to 
investigate the actual state of distance social work education in some Arab countries during COVID-19 pandemic

\section{Study Objectives:}

Main objective: describe and analyse the reality of distance social work education in the Arab world in the light of COVID-19 pandemic

Sub- objectives: This previous aim is achieved in term of the following sub - objectives:

1) Identifying faculty members' attitudes towards distance social work education system.

2) Determining the degree of achievement of social work education objectives in the light of distance education system as perceived by Faculty members.

3) Identifying the obstacles that face distance social work education as perceived by Faculty members.

4) Investigating the correlation between each variable of the abovementioned variables and some demographic characteristics among Faculty members participating in the study.

\section{Literature Review}

\section{Distance Social Work Education Concept}

Distance Education is one of the terms that refer to education and teaching processes that not take place via face to face interaction between the teachers and the learners. Also there are common other terms that are synonymous to that term and used by some researchers interested in educational systems and processes to refer to this educational system as: electronic education and online education.

In short, distance education is a teaching method through which the teachers communicate with the students via specific educational media that are used in case there are restrictions that limit using traditional educational methods (Demirbilek, M., 2019.16). This educational system includes a number of education system elements (teacher - learner - 
administration) that meet via electronic communication means for knowledge and thoughts sharing. Through these process web applications are used instead of face to face interaction (Al Qahtani, Mohammed, 2010, 22).

Distance Education can be defined as an educational and learning method by using electronic media in delivering and receiving information between the teacher and the learner like computers and webs, media like videos, electronic libraries and internet etc. This usage can be simple as using these electronic means in exposing and discussing information in the classes or the training rooms or may reach the so-called virtual classes where the educational process takes place (Abo Al Nasr, Medhat 2017, 68).

Concerning the concept of distance social work education specifically, it is defined as the provision of bachelor's, master's, and doctoral social work courses and programs over the Internet using specific programs and not face-to-face (Singh, 2016, 7). Also distance education is defined within the social work as: a modern system in which the social work education process is completed with maintaining all its elements including the students, the faculty members, the educational Objectives, administration and content and this process is based on using modern technological means to deliver knowledge, skills and values of social work from the teachers to the students (Al Naggar, Atef 2019, 693).

Within the mentioned above framework, social work education can be defined in the current study as: A relatively new educational system in which social service teachers are separated from their students, and the traditional environment for teaching and teaching transferred from university or institute to multiple geographically diverse environments, this process takes place through media, communication methods or different technology through synchronous communication or asynchronous communication so as to transfer and acquire each of knowledge, skills and professional values. 


\section{Social work education keeping up with technology:}

Although more than a hundred and fifty years have passed since distance education efforts, they are still new to teaching social work courses. Distance education was included in social work with a recent history exceeding 25 years through various development stages imposed by technological progress and the growing need for social workers (Reamer, F. 2019,420)

It is not possible to make social work education completely technology-based. Education needs support through a flexible learning environment where people can interact personally and face to face in their social context. In social work lectures, it is not just knowledge, skill, and value sharing on a cognitive and behavioural basis. There is also an emotional exchange between the student, the learning environment, and all faculty.

On the contrary, many researchers in social work defend the need to develop distance education programs because of their contribution to transforming social work education by providing an opportunity for the participation of clients and social workers working in the field with faculty members and students. Where social work education exceeds the constraints of time and space and provides an opportunity for all students around the world to learn social work (Moore, B., 2008,592). On the other hand, distance education using modern technology provides social work students unless the traditional education system can provide it. Through elearning, educational tools can be designed to fit unique learning styles that are an opportunity for students. However, this reality carries within it a set of thorny and troubling issues such as product quality, academic honesty, integrity, the extent of the ability of social work students to learn basic and clinical skills via the internet, the extent of the ability of technological tools to assess the quality of a student's professional behavior, the effectiveness of fieldwork and building relationships between students, faculty members, and supervisors. 
Also, distance social work education using technological tools can face many of the difficulties and challenges created by the high standards level associated with rigorous social work education (Reamer, F., 2013,381). However, research comparing the traditional and internet-based social work education model in terms of social work student's acquisition of knowledge demonstrated no differences among students in different outcome measures (York, R. O, 2008,157). Therefore, some researchers argue that it instead of the tendency to marginalize distance education, social work faculty members should recognize the importance of distance education and the opportunities it provides for many students (Collins, S., 2008,437)

Since online learning in social work education seemed to spread in keeping with technology, it is necessary to set quality standards in social work courses via the Internet. There is no doubt that students' regular feedback can contribute to the quality assurance standards for online education (Secret et al., 2016,31). Consequently, guarantees must be provided to maintain the quality of social work education remotely. This is represented by developing a training model that focuses on teaching and the values of social work and technology to train social work faculty members to provide social work courses online in high quality (Baez et al., 2019,516).

In general, it can be said Keeping pace with technology and integrating it into social work education is necessary with technological progress. Still, its success requires the development of mechanisms that maintain the high quality of social work education. , many countries tentatively are not inclined to teach distance social work due to the negative attitude towards distance education for social work faculty and their desire to preserve the traditional trend of social work education on the one hand and the weak technology infrastructure in Most of these countries. However, the Coronavirus (COVID 19) pandemic forced all social work faculty to apply to distance education and use electronic tools in teaching social work. 


\section{Distance social work education in response to the COVID 19 pandemic:}

The Coronavirus pandemic affected every aspect of life, including higher education. This pandemic has created disturbances in educational institutions, whether in the initiation of distance education or troubled assessments, and a set of adverse effects on students and faculty members in general. The start of distance education was as a quick response to the repercussions of COVID 19, and this response had a definite impact on the progress of the educational process at its various levels (Burgess \& Sievertsen, 2020).Consequently, the Coronavirus pandemic imposed online education on all sciences in an unprecedented way and made the use of technology in education and resort to distance education as tools to maintain the normal status of education and thus revolutionized the field of distance education (Slanetz et al., 2020,743).However, the response of higher education systems to the Coronavirus pandemic in many countries was weak due to the lack of preparedness of the infrastructure of the distance education system in addition to the lack of readiness and readiness of faculty members and the inadequate access of students to education integrated with technology and electronic tools (Ali, W., 2020.17-18).

There is no doubt that social work education in the world in general and in the Arab world, in particular, has been greatly affected by the pandemic of COVID 19, and this situation was a source of concern for students and faculty members in social work departments and programs (Tedam,P., 2020,52).Distance social work education during the precautionary measures of COVID 19 was as a strategy followed as a quick response to the crisis. However, this new system of distance education caused many social work teachers and faculty members' suffering due to it being the first experience of social work courses via the Internet. The students found themselves able to deal with distance education. Still, they felt dissatisfied by the absence of social interactions and the inability to form relationships in a virtual society, which affected their enthusiasm (Smoyer et al., 2020,2-3). In addition to students' inability to continue field training in the vast majority of social work institutions, this situation also 
posed significant problems for social work students in terms of education and practice (Dominelli et al., 2020.58).

Looking at the nature and spread of the Coronavirus, we find that integrating technology in social work and distance education has become inevitable in response to the pandemic. However, the high quality of social work teaching and its nature requires existing to follow specific criteria to maintain this quality in either keeping pace with technology or responding to the COVID 19 pandemic. In this regard, the Social Work Education Council has developed several guidelines for accrediting social work programs in the context of distance education during the Coronavirus pandemic. These guidelines aim to preserve the safety of students and to maintain the quality of social work education at the same time. The instructions are represented in suspending or delay field training during the COVID 19 period to maintain student safety, reduce field-training hours, and calculate field activities remotely (CSWE, 2020).

The Coved 19 pandemic has made distance education the primary source of education. Consequently, academics' negative attitudes in social work towards distance education are supposed to be reviewed with many proposals to develop distance social work education and support it as an unavoidable reality. These attitudes towards distance social work education may differ from one country to another because of many of the variables mentioned above, such as readiness of the technology infrastructure, teachers' ability to deal with electronic tools, and the ability of students to access them.

\section{Methodology:}

This study is descriptive and analytical as it aims at describing and analyzing the reality of distance social work education in the light of COVID19 Pandemic. It used the social survey approach of the sample Which determines the characteristics of the phenomena and the relationship between the variables. It was initially planned that the study would be implemented in six Arab countries concerned with social work education, respectively, Egypt, Saudi Arabia, Jordan, Oman, Kuwait, and Emirates. 
However, due to the small number of faculty members in the last three countries who completed the tool used to collect data, the first three countries were retained.

\section{Study Questions:}

The current study seeks to answer the following main question: "What is the reality of distance social work education system in the Arab World in the light of COVID-19 Pandemic"? The following sub-questions are derived from the previous main question:

1) What are social work faculty members' attitudes in the Arab World towards distance social work education system?

2) Are there statistically significant differences at $(\alpha=0.05)$ level of significance in faculty members' attitudes towards distance social work education system according to variables of \{Gender-Academic degree - Country - Age - Experience (yrs)\}?

3) What is the degree of achievement of social work education objectives in the light of distance education system as perceived by Faculty members?

4) Are there statistically significant differences at ( $\alpha=0.05$ ) level of significance in the degree of achievement of social work education objectives distance education system according to variables of \{Gender-Academic degree - Country - Age - Experience (yrs)\}?

5) What are the obstacles that face distance social work education system as perceived by Faculty members?

6) Are there statistically significant differences at $(\alpha=0.05)$ level of significance in the obstacles that face distance social work education according to variables of $\{$ Gender- Academic degree Country - Age - Experience (yrs)\}?

\section{Sample:}

The study sample amounted to (248) faculty members, (132) from Egypt, (88) from Saudi Arabia, and (28) from Jordan. Researcher have found that the vast majority of faculty members working in social work departments and programs in Jordanian universities are specialists in 
sociology. The data were collected April and May during completing the second semester, Spring 2020, when the Arab universities were forced to adopt the education system at a distance in light of the Coronavirus (COVID19) Pandemic.

\section{Instrument:}

The study relied on an electronic questionnaire form for collecting information from the sample https://forms.gle/qz9J3rhFTtfaFrCF8. The questionnaire consists of two parts: The first part includes the preliminary information of the participants as (Gender-Age- Academic degreeExperience (yrs)- Country) while the second part includes the primary measurement dimensions which are as follows respectively:

- faculty members' attitudes towards distance social work education.

- Degree of achievement of social work education objectives under the distance education system

- The obstacles that face distance social work education.

A five -point scale (I agree completely - I agree - I quite agree - I disagree - I completely disagree) used to measure the participant's responses on items related to attitudes variable and positive items was scored $(1,2,3,4,5)$ and the contrary was for negative items. Also a five-point scale was used to measure items concerning obstacles variable. A threepoint scale (It can be applied wholly- It can be applied partially - It cannot be applied) was used to measure degree of achievement of social work education objectives variable through the following values $(1,2,3)$ respectively. Concerning attitudes types on first variable and the participants' responses levels on the second and the third variables they were determined as follows:

- Arithmetic mean (3) was used as a reference value to identify the attitudes types in which value below 3 refers to negative attitudes and value above 3 refers to positive attitudes.

- The participant's responses levels on the variable related to degree of achievement of social work education objectives were 
classified as follows: low $=(1-1.67)$, average $=(1.68-2.33)$, high $=$ $(2.34-3)$.

- The participants' responses in relation to obstacles variable were classified as follows: low $=(1-2.33)$. average $=(2.34-3.67)$, high $=$ $(3.68-5)$.

Face validity of the questionnaire form was examined via providing it to five raters, who are professors of social work, to give their opinions about the questionnaire items, and the integrity of the phrases that make up each items. This led to some mild changes which were reframe the language of three phrases, replacement of two phrases and also the remaining phrases had the agreement of the raters. After that the questionnaire reliability was examined through Method of test - retest by applying it on a sample of 25 Faculty members (out of the study sample) and the reliability coefficient on the questionnaire variables ranged from $(0.72-0.81)$

\section{Methods of statistical analysis:}

The data processed by Statistical Package for the Social Sciences (SPSS. V. 17.0), It have been used and applied of a variety of statistical coefficients and methods, to answer the study questions which are:

- Frequency and percentage

- Mean and Standard Deviation,

- F-test and Pearson's Correlation Coefficients

- Structural Equation Modelling (SEM) approach.

\section{Study Results:}

\section{- Participants}

Table (1):

Summary characteristics for demographic variables

\begin{tabular}{||c|c|c|c||}
\hline \multicolumn{2}{|c|}{ Qualitative variables } & Number & Percent \\
\hline Variable & Value Label & & \\
\hline Gender & Male & 144 & $58 \%$ \\
\cline { 2 - 4 } & Female & 104 & $42 \%$ \\
\hline Academic degree & Professor & 79 & $32 \%$ \\
\cline { 2 - 4 } & $\begin{array}{c}\text { Associate } \\
\text { Professor }\end{array}$ & 70 & $28 \%$ \\
\hline
\end{tabular}




\begin{tabular}{||c|c|c|c|}
\hline \multirow{2}{*}{ Country } & $\begin{array}{c}\text { Assistant } \\
\text { Professor }\end{array}$ & 99 & $40 \%$ \\
\hline & Egypt & 132 & $53 \%$ \\
\cline { 2 - 4 } & Saudi Arabia & 88 & $35 \%$ \\
\cline { 2 - 4 } & Jordan & 28 & $11 \%$ \\
\hline Quantitative variables & Mean & Std. Deviation \\
\hline \multicolumn{2}{|c|}{ Age } & 45 & 7.92 \\
\hline \multicolumn{2}{|c|}{ Experience (yrs) } & 15.9 & 9.08 \\
\hline
\end{tabular}

Table (1) reports that there were 144(58\%) male and 104(42\%) female out of 248 participants in total, those who represent the sample of the study from the faculty members of the colleges and departments of social work in some Arab countries. The academic degree for participants was classified as 79 (32\%) full professor, 70(28\%) associate professor, and 99 (40\%) assistant professor. Regarding the country of work, the majority 132 (53\%) were working in Egypt, 88 (35\%) were in Saudi Arabia, and 28 (11\%) were in Jordan, also table shows that the mean age, in years, was 45 (SD = 7.92), however the mean of experience (yrs) was 15.9 ( $S D=9.08$ )

- The results of the first sub-question:

What are social work faculty members' attitudes in the Arab World towards distance social work education system? The results of the answer to this question are made clear through the following table: 
Table (2)

Faculty members' attitudes towards distance social work education.

\begin{tabular}{|c|l|c|c|c|c||}
\hline $\mathbf{N}$ & \multicolumn{1}{|c|}{ Item } & Mean & $\begin{array}{c}\text { Std. } \\
\text { Deviation }\end{array}$ & $\begin{array}{c}\text { Attitude } \\
\text { type }\end{array}$ & Rank \\
\hline 1 & $\begin{array}{l}\text { The distance education system is } \\
\text { not compatible with the special } \\
\text { nature of the social work } \\
\text { profession. }\end{array}$ & 2.15 & 1.215 & negative & 6 \\
\hline 2 & $\begin{array}{l}\text { The distance education system } \\
\text { reduces the financial cost of social } \\
\text { work education. }\end{array}$ & 3.44 & 1.009 & positive & 1 \\
\hline 3 & $\begin{array}{l}\text { The distance education system } \\
\text { provides creative opportunities for } \\
\text { social work students, which not } \\
\text { offered by traditional education. }\end{array}$ & 1.92 & 1.091 & negative & 8 \\
\hline 4 & $\begin{array}{l}\text { Distance education is an effective } \\
\text { system that increases the } \\
\text { capabilities and competencies of } \\
\text { social work educators. }\end{array}$ & 3.28 & 1.115 & positive & 2 \\
\hline 5 & $\begin{array}{l}\text { The distance education system can } \\
\text { contribute to improving the quality } \\
\text { of social work education. }\end{array}$ & 2.26 & 1.049 & negative & 5 \\
\hline 6 & $\begin{array}{l}\text { Adopting a system of distance } \\
\text { social work education, it could } \\
\text { threaten my job security. }\end{array}$ & 2.02 & 1.177 & negative & 7 \\
\hline 7 & $\begin{array}{l}\text { I expect that distance social work } \\
\text { education will not win the } \\
\text { recognition of society and its social } \\
\text { institutions. }\end{array}$ & 1.87 & 1.038 & negative & 9 \\
\hline 8 & $\begin{array}{l}\text { The distance education system } \\
\text { may negatively affect my scientific } \\
\text { standing in social work. }\end{array}$ & 3.23 & 1.236 & positive & 3 \\
\hline 9 & $\begin{array}{l}\text { I see that the disadvantages of } \\
\text { distance social work education } \\
\text { system outweigh its advantages. }\end{array}$ & 1.74 & 1.081 & negative & 10 \\
\hline 10 & $\begin{array}{l}\text { Under the distance education } \\
\text { system, I am concerned about the } \\
\text { future of social work education } \\
\text { and practice. }\end{array}$ & 2.63 & 1.098 & negative & 4 \\
\hline & 2.45 & 1.067 & negative & \\
\hline
\end{tabular}

Table 2 confirmed distance social work education was not supported by the majority of the study sample members in which the total score of that 
variable was (Mean $=2.45 ; 1.067$ ), and this value indicated faculty members' attitudes towards this educational system in general were negative. As indicated only three items refer to positive attitudes in which they had arithmetic means from $(3.23-3.44)$. The item of the first rank indicated the distance education system reduces the financial cost of social work education in which it had (Mean=3.44; SD=1.009). The item of the second rank indicated distance education is an effective system that increases the capabilities and competencies of social work educators and it had (Mean =3.23; $S D=1.115$ ). The item of the third rank indicated the distance education system may negatively affect my scientific standing in social work in which it had (Mean =3.28; SD=1.236).

The remaining items of this dimension refer to the negative attitudes in which arithmetic means values ranged from $(1.74-2.63)$ and the ranks were from $4-10$. The item that had the lowest value was "The distance education system provides creative opportunities for social work students, which not offered by traditional education" and was of the eighth rank (Mean =1.92; SD=1.091). Then followed by the phrase that states "Distance social work education will not win the recognition of society and its social institutions" and was of the ninth rank (Mean =1.87; SD=1.038). The item "The disadvantages of distance social work education system outweigh its disadvantages" was of the ninth (the final) rank (Mean=1.74; SD=1.081

\section{- The results of the second sub-question:}

Are there statistically significant differences at $(\alpha=0.05)$ level of significance in faculty members' attitudes towards distance social work education system according to variables of \{Gender- Academic degree Country - Age - Experience (yrs)\}? The following table shows the results of the answer to this question: 
Table (3)

The relation between faculty members' attitudes towards distance social work system and their demographic characteristics.

\begin{tabular}{|c|c|c|c|c|c|}
\hline \multicolumn{2}{|c|}{ Qualitative variables } & \multirow[t]{2}{*}{ Mean } & \multirow{2}{*}{$\begin{array}{c}\text { Std. } \\
\text { Deviation }\end{array}$} & \multirow[t]{2}{*}{$\mathrm{F}$} & \multirow[t]{2}{*}{ Sig. } \\
\hline Variable & Value Label & & & & \\
\hline \multirow[t]{2}{*}{ Gender } & Male & 3.5255 & 0.86171 & \multirow[t]{2}{*}{0.801} & \multirow[t]{2}{*}{0.372} \\
\hline & Female & 3.4696 & 0.77993 & & \\
\hline \multirow{3}{*}{$\begin{array}{l}\text { Academic } \\
\text { degree }\end{array}$} & Professor & 3.5745 & 0.84365 & \multirow[t]{3}{*}{1.154} & \multirow[t]{3}{*}{0.418} \\
\hline & $\begin{array}{l}\text { Associate } \\
\text { Professor }\end{array}$ & 3.4034 & 0.85721 & & \\
\hline & $\begin{array}{l}\text { Assistant } \\
\text { Professor }\end{array}$ & 3.4702 & 0.61706 & & \\
\hline \multirow[t]{3}{*}{ Country } & Egypt & 3.6245 & 0.74223 & \multirow[t]{3}{*}{1.421} & \multirow[t]{3}{*}{0.243} \\
\hline & Saudi Arabia & 3.4857 & 0.95162 & & \\
\hline & Jordan & 3.4158 & 0.79303 & & \\
\hline \multicolumn{2}{|c|}{ Quantitative variables } & \multicolumn{2}{|c|}{$\begin{array}{c}\text { Pearson's correlation } \\
\text { coefficients }\end{array}$} & \multicolumn{2}{|c|}{ significance level } \\
\hline \multicolumn{2}{|c|}{ Age } & \multicolumn{2}{|c|}{-1.045} & \multicolumn{2}{|c|}{0.05} \\
\hline \multicolumn{2}{|c|}{ Experience (yrs) } & \multicolumn{2}{|c|}{-1.168} & \multicolumn{2}{|c|}{0.05} \\
\hline
\end{tabular}

Table (3) indicates there are no statistically significant differences in faculty members' attitudes towards distance social work education system attributed to variables of gender, academic degree, country in which Fvalue of the relation between those variables were $(0.801,1.154,1.421)$ respectively. Also Sig- value was $(0.372,0.418$, and 0.243$)$ and all these values are not statistically significant as they are above 0.05 . Also the table (3) indicates there are statistically significant negative differences between those attitudes and variables of age and experience (yrs) in which Pearson correlation coefficients values were $(-1.045,-1.168)$ and they are statistically significant at $(\alpha=0.05)$ level of significance.

\section{- The results of the third sub-question:}

What is the degree of achievement of social work education objectives in the light of distance education system as perceived by faculty members? The results of the answer to this question are made clear through the following table: 
Table (4)

Degree of achievement of social work education objectives in the light of distance education system as perceived

by faculty members.

\begin{tabular}{|c|l|c|c|c|c|}
\hline $\mathbf{N}$ & \multicolumn{1}{|c|}{ Item } & Mean & $\begin{array}{c}\text { Std. } \\
\text { Deviation }\end{array}$ & Level & Rank \\
\hline 1 & $\begin{array}{l}\text { Provide students with diverse } \\
\text { scientific knowledge to } \\
\text { understand clients behaviour }\end{array}$ & 2.36 & 0.558 & high & 1 \\
\hline 2 & $\begin{array}{l}\text { Preparing students to learn the } \\
\text { principles of social justice and } \\
\text { applying them in practical } \\
\text { situations. }\end{array}$ & 1.66 & 0.753 & low & 4 \\
\hline 3 & $\begin{array}{l}\text { Training students to practice } \\
\text { the professional values that } \\
\text { should be adhered to when } \\
\text { dealing with clients. }\end{array}$ & 1.37 & 0.622 & low & 7 \\
\hline 4 & $\begin{array}{l}\text { Developing students' ability to } \\
\text { understand themselves. }\end{array}$ & 1.82 & 0.649 & average & 2 \\
\hline 5 & $\begin{array}{l}\text { Contribute to the formation of a } \\
\text { professional personality for } \\
\text { students. }\end{array}$ & 1.49 & 0.661 & low & 6 \\
\hline 6 & $\begin{array}{l}\text { Providing students with } \\
\text { professional intervention skills } \\
\text { with the client's systems. }\end{array}$ & 1.28 & 0.547 & low & 8 \\
\hline 7 & $\begin{array}{l}\text { Prepare students to pursue } \\
\text { professional development, } \\
\text { including the completion of } \\
\text { graduate studies in the future. }\end{array}$ & 1.74 & 0.736 & low & 3 \\
\hline 8 & $\begin{array}{l}\text { Linking between the theoretical } \\
\text { preparation of students and } \\
\text { field practice }\end{array}$ & 1.51 & 0.636 & low & 5 \\
\hline & 1.61 & 0.462 & low & \\
\hline
\end{tabular}

Table (4) indicates degree of achievement of social work education objectives in the light of distance education as perceived by faculty members was low in which total score was (Mean $=1.61$; SD $=0.462$ ) so, it was in the low level. Also table (4) indicates the aim "Providing students with diverse scientific knowledge to understand clients behavior "was in the first rank (Mean $=2.36$; SD = 0.558). The aim "Developing students ability to understand themselves " was in the second rank (Mean =1.61; $S D=0.462$ ) and also it was the only aim that was in the moderate level while 
other objectives of social work were in the low level beginning from the aim "Prepare students to pursue professional development, including the completion of graduate studies in the future " which had the third rank (Mean $=1.74 ;$ SD $=0.736$ ) to the aim " Linking between the theoretical preparation of students and field practice with various social institutions " which was in the eighth (final) rank (Mean=1.28; SD=0.547).

\section{- The results of the fourth sub-question:}

Are there statistically significant differences at $(\alpha=0.05)$ level of significance in the degree of achievement of social work education objectives under distance education system according to variables of \{Gender- Academic degree - Country - Age - Experience (yrs)\}? The following table shows the results of the answer to this question:

Table (5)

The relation between degree of achievement of social work education objectives and demographic characteristics

of faculty members

\begin{tabular}{|c|c|c|c|c|c|}
\hline \multicolumn{2}{|c|}{ Qualitative variables } & \multirow[t]{2}{*}{ Mean } & \multirow{2}{*}{$\begin{array}{c}\text { Std. } \\
\text { Deviation }\end{array}$} & \multirow[t]{2}{*}{$\mathrm{F}$} & \multirow[t]{2}{*}{ Sig. } \\
\hline Variable & Value Label & & & & \\
\hline \multirow[t]{2}{*}{ Gender } & Male & 1.58941 & 0.476654 & \multirow[t]{2}{*}{0.886} & \multirow[t]{2}{*}{0.348} \\
\hline & Female & 1.64543 & 0.442409 & & \\
\hline \multirow{3}{*}{$\begin{array}{c}\text { Academic } \\
\text { degree }\end{array}$} & Professor & 1.58428 & 0.447772 & \multirow[t]{3}{*}{0.539} & \multirow[t]{3}{*}{0.584} \\
\hline & $\begin{array}{l}\text { Associate } \\
\text { Professor }\end{array}$ & 1.64631 & 0.467792 & & \\
\hline & $\begin{array}{l}\text { Assistant } \\
\text { Professor }\end{array}$ & 1.64286 & 0.520099 & & \\
\hline \multirow[t]{3}{*}{ Country } & Egypt & 1.56171 & 0.452855 & \multirow[t]{3}{*}{0.709} & \multirow[t]{3}{*}{0.493} \\
\hline & Saudi Arabia & 1.63571 & 0.482832 & & \\
\hline & Jordan & 1.63763 & 0.456841 & & \\
\hline \multicolumn{2}{|c|}{ Quantitative variables } & \multicolumn{2}{|c|}{$\begin{array}{c}\text { Pearson's correlation } \\
\text { coefficients }\end{array}$} & \multicolumn{2}{|c|}{ significance leve } \\
\hline \multicolumn{2}{|c|}{ Age } & \multicolumn{2}{|c|}{-1.007} & \multicolumn{2}{|c|}{0.05} \\
\hline \multicolumn{2}{|c|}{ Experience (yrs) } & \multicolumn{2}{|c|}{-0.832} & \multicolumn{2}{|c|}{0.01} \\
\hline
\end{tabular}

Table (5) indicates there are no statistically significant differences between the participants scores means on the variable related to degree of achievement of social work education objectives under distance education 
system as perceived by faculty members and some demographic characteristics including gender, academic degree and country in which Fvalue of the relation between those variables was $(0.886,0.539,0.709)$ respectively and Sig- value was $(0.348,0.548,0.493)$ and all these values are not statistically significant as they are above 0.05 . Moreover, the table confirms there are statistically significant negative differences between degree of achievement of social work education objectives and age variable in which Pearson correlation coefficients values were -1.007 and they are statistically significant at $(\alpha=0.05)$ level of significance. Also, there are statistically significant negative differences between objectives fulfilment degree and experience (yrs) variable in which Pearson correlation coefficients values were -0.832 and they are statistically significant at $(\alpha=$ 0.01 ) level of significance.

In short, this means that the perception of faculty members of degree of achievement of social work education objectives in the light of distance education system is different among themselves according to the age and experience (yrs) only, In a more specific sense, the higher the age or experience of the faculty members, the lower their perception and evaluation of degree of achievement of social work education objectives under this educational system. and vice versa, the lower their age or experience (yrs.), the higher their evaluation and perceptions to the degree of achieving those objectives

\section{- The results of the fifth sub-question:}

What are the obstacles that face distance social work education system as perceived by faculty members? The results of the answer to this question are made clear through the following table: 
Table (6):

The obstacles that face distance social work education as perceived by faculty members.

\begin{tabular}{|c|l|c|c|c|c||}
\hline $\mathbf{N}$ & \multicolumn{1}{|c|}{ Item } & Mean & $\begin{array}{c}\text { Std. } \\
\text { Deviation }\end{array}$ & Rank & Rank \\
\hline 1 & $\begin{array}{l}\text { Inability to apply field training } \\
\text { plans and }\end{array}$ & 4.39 & 0.966 & high & 1 \\
\hline 2 & $\begin{array}{l}\text { The absence of a diverse social } \\
\text { environment that contributes } \\
\text { to the development of } \\
\text { students' professional } \\
\text { personality. }\end{array}$ & 4.15 & 0.835 & high & 3 \\
\hline 3 & $\begin{array}{l}\text { The lack of electronic } \\
\text { educational courses in social } \\
\text { work. }\end{array}$ & 3.42 & 0.704 & average & 8 \\
\hline 4 & $\begin{array}{l}\text { Lack of direct interaction } \\
\text { between students which } \\
\text { supports their human } \\
\text { experiences. }\end{array}$ & 4.27 & 0.893 & high & 2 \\
\hline 5 & $\begin{array}{l}\text { Inability to use the active } \\
\text { learning methods needed by } \\
\text { social work students. }\end{array}$ & 3.56 & 1.006 & average & 7 \\
\hline 6 & $\begin{array}{l}\text { Difficulty in controlling the } \\
\text { evaluation process of } \\
\text { student's performance and } \\
\text { their professional } \\
\text { development. }\end{array}$ & 3.95 & 0.979 & high & 5 \\
\hline 7 & $\begin{array}{l}\text { Not being able to practice } \\
\text { group and cooperative work } \\
\text { that distinguishes social work } \\
\text { students. }\end{array}$ & 3.62 & 0.906 & average \\
\hline 8 & $\begin{array}{l}\text { The difficulty of preparing and } \\
\text { qualifying students according } \\
\text { to the current quality } \\
\text { standards and requirements } \\
\text { of the labor market }\end{array}$ & 3.99 & 0.966 & high & 4 \\
\hline & \begin{tabular}{l} 
Total \\
\hline
\end{tabular} & 0.706 & high & \\
\hline
\end{tabular}

Table (6) indicates there are various obstacles that face distance social work education in which the total value of this variable (Mean $=3.92 ; \mathrm{SD}=$ 0.706). The variable of the first rank was "Inability to apply field training plans" (Mean $=4.39 ;$ SD = 0.966), the variable of the second rank was " Lack of direct interaction between students which supports their human 
experiences " (Mean $=4.27 ; \mathrm{SD}=0.893)$. On the other side, three obstacles were moderate in which arithmetic means values ranged from $(3.62-3.42)$ and their ranks were from $6-8$. These variables were " Not being able to practice group and cooperative work that distinguishes social work students " (Mean=3.62; SD=0.906), "Inability to use the active learning methods needed by social work students " (Mean=3.56; SD=1.006) and " The lack of electronic educational courses in social work " (Mean $=3.42$; SD $=0.704)$.

\section{- The results of the sixth sub-question:}

Are there statistically significant differences at $(\alpha=0.05$ ) level of significance in the obstacles that face distance social work education according to variables of \{Gender- Academic degree - Country - Age Experience (yrs)\}? The following table shows the results of the answer to this question:

Table (7)

The relation between the obstacles that face distance social work education and demographic characteristics of faculty members.

\begin{tabular}{|c|c|c|c|c|c|}
\hline \multicolumn{2}{|c|}{ Qualitative variables } & \multirow[t]{2}{*}{ Mean } & \multirow{2}{*}{$\begin{array}{c}\text { Std. } \\
\text { Deviation }\end{array}$} & \multirow[t]{2}{*}{$\bar{F}$} & \multirow[t]{2}{*}{ Sig. } \\
\hline Variable & Value Label & & & & \\
\hline \multirow[t]{2}{*}{ Gender } & Male & 4.04167 & 0.758979 & \multirow[t]{2}{*}{0.238} & \multirow[t]{2}{*}{0.632} \\
\hline & Female & 4.08534 & 0.629538 & & \\
\hline \multirow{3}{*}{$\begin{array}{l}\text { Academic } \\
\text { degree }\end{array}$} & Professor & 4.11932 & 0.655435 & \multirow[t]{3}{*}{1.218} & \multirow[t]{3}{*}{0.298} \\
\hline & $\begin{array}{l}\text { Associate } \\
\text { Professor }\end{array}$ & 4.01705 & 0.771991 & & \\
\hline & $\begin{array}{l}\text { Assistant } \\
\text { Professor }\end{array}$ & 3.91518 & 0.719321 & & \\
\hline \multirow[t]{3}{*}{ Country } & Egypt & 4.1962 & 0.610631 & \multirow[t]{3}{*}{2.251} & \multirow[t]{3}{*}{0.107} \\
\hline & Saudi Arabia & 3.97143 & 0.815989 & & \\
\hline & Jordan & 4.01389 & 0.685558 & & \\
\hline \multicolumn{2}{|c|}{ Quantitative variables } & \multicolumn{2}{|c|}{$\begin{array}{c}\text { Pearson's correlation } \\
\text { coefficients }\end{array}$} & \multicolumn{2}{|c|}{ significance level } \\
\hline \multicolumn{2}{|c|}{ Age } & \multicolumn{2}{|c|}{0.621} & \multicolumn{2}{|c|}{0.05} \\
\hline \multicolumn{2}{|c|}{ Experience (yrs) } & \multicolumn{2}{|c|}{0.374} & \multicolumn{2}{|c|}{0.05} \\
\hline
\end{tabular}

Table (7) indicates there are no statistically significant differences between the obstacles that face distance social work education and demographic characteristics of faculty members including gender, 
academic degree and country in which F-value of the correlation between those variables was $(0.238,1.218,2.251)$ Sig- value was $(0.632,0.298$, $0.107)$ respectively and all these values are not statistically significant as they are above 0.05 . Also, the table shows there are statistically, significant positive differences between those obstacles and variables of age and experience (yrs) in which Pearson correlation coefficients values were $(0.621,0.374)$ and they are statistically significant at $(\alpha=0.05)$ level of significance.

According to tables $(3,5,7)$, it appears in general quantitative demographic variables including age and experience (yrs) have a big impact on the participants responses related to all primary variables of the study (attitudes -objectives achievement - obstacles ). Therefore, the correlation between those variables each other can be made clear through a path analysis model that is shown in figure (2) using a Structural Equation Modelling (SEM) approach.

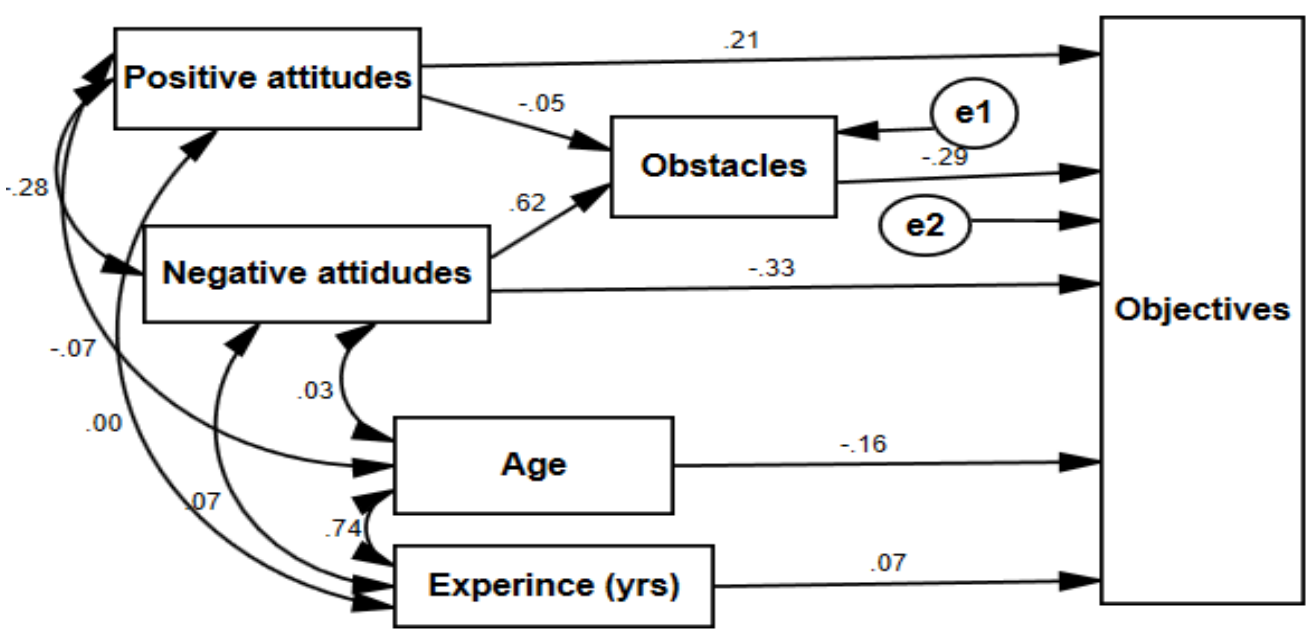

Figure (1)

Path model for relation between the basic variables of the study and quantitative demographic variables \{age - experience (yrs)\} among the participants

\section{Discussion}

This study sought to know the reality of distance social work education in the Arab world after all colleges and institutes of social work in the Arab countries had to adopt distance education in light of the 
Coronavirus pandemic. This included shedding light on three variables, the first of which is: the attitudes of faculty members towards this new system, which they are not familiar with and have not worked with before in the scope of social work education, and the second is their view on the objectives of social work education that can be achieved, and the third variable It was related to the obstacles that may face the present and future of social work education when this system is introduced.

The study results came to confirm that the attitudes of the Arab faculty members towards teaching social work from a distance were generally negative. This result is in direct agreement with Zidan, T. (2015) study results, which confirmed that the distance education system had not been supported and accepted by social work faculty members. Conversely, this finding was not in agreement with those of Smith et al. (2018) confirmed the acceptance and satisfaction of both teachers and students of social work for the distance education system, as a result of the many advantages that this system provides from their point of view, the most prominent of which is also the study results indicated saving time and reducing the burdens and pressures that fall on the shoulders of teachers and students. This finding was also not in agreement with the McAuliffe (2019) study, which concluded that distance social work education is the future path. Therefore, social work faculty members 'attitudes should be positive towards e-learning and work to overcome obstacles that could prevent social work education objectives by showing more attention and allocating time, and experimenting with various tools

Concerning the degree of achievement of social work education objectives under the distance education system, according to faculty members' perceptions, the results of this study revealed that the vast majority of the participants also decided that the vast majority of social work education objectives cannot be achieved, either fully or partially, Within the framework of this educational system This confirms its ineffectiveness in reaching the desired results from the education of social work in general, and this result was consistent with the results of a study Levin et al. (2018) Which indicated that social work teachers view distance 
education as less effective than education on the ground in helping students meet the competencies of the Social Work Education Council.. This agrees with Kurzman, P. (2019) who believes that distance education does not achieve the expected results and outcomes for students and social work faculty members alike.

On the other hand, the results of the study revealed the multiplicity and diversity of obstacles that threaten social work education in light of this new educational system. Which came in the forefront of each inability to apply field training plans, Lack of direct interaction between students, which supports their human experiences, and the absence of a diverse social environment that contributes to the development of students' professional personality This finding is in agreement with the results of Vernon et al. (2009) - Szilagyi L. et al., (2013) - studies all of which emphasized that the use of distance education system technologies or elearning in social work faces many obstacles and challenges, the most prominent of which are, for example, but not limited to the lack of experience of faculty members in using technology and faculty members 'incomplete understanding of the most effective teaching method in communicating topics and student interaction and engagement with the course

In addition to the previous results, the statistical analysis also showed that the quantitative demographic variables represented by (GenderAcademic degree -country) had no role in influencing the participants' perceptions and opinions related to all the basic variables of the study (Attitudes - Achieving Objectives- Obstacles). This result is consistent with Al-Talani ,Nedhal (2012), which confirmed that there are no statistically significant differences in the attitudes of faculty members towards usiing elearning in university teaching according to gender, as well as with AlShaboul, Muhannad (2014) results which concluded that faculty members' attitudes towards distance education, as well as their view on obstacles to its use, are not affected by the variable of academic degree, and also this result was supported Al - Shahri ,Sami (2019), results which resulted in the 
absence of a relationship between faculty members' attitudes towards using e-learning in university teaching, and for both sex and nationality

Contrary to the foregoing, the results of the study concluded that the quantitative demographic variables represented by both age and age and experience (yrs) have a major role in influencing the participants' responses related to all the basic variables of the study (Attitudes - Achieving Objectives - Obstacles), which means whenever the faculty members' age and experience (yrs) crease, whenever their attitudes towards distance education negative, whenever they were less convinced of This educational system ability to achieve social work education objectives. Consequently, they also increased their sense of the obstacles they face during the educational process Conversely, whenever the participants' age and experience decreases, whenever their attitudes towards distance education positive, whenever their conviction and support for this system and the social work education objectives that can be achieved through it are increased. Consequently, the degree of their sense of the obstacles they face during the educational process decreased.

This can be explained in light of the nature and characteristics of the faculty members' age stage. People older than them usually tend to stick to the traditional systems that they have accustomed to and become accustomed to. Indeed, many of them may show resistance to modern technological systems used in educational processes, especially if they require special skills and abilities. It may not be available to many of them, and therefore they do not accept this type of education and take a negative attitude towards it. Of course, these negative trends and attitudes affect their assessment of the extent to which the objectives of social work education are achieved and their perception and it also affects awareness of the obstacles that hinder the educational process. In this context, Tuncay, T. (2020) indicated that whenever the attitudes towards distance social work education negative whenever the outputs of social work education are weak and that this leads to the emergence of many obstacles such as the absence of direct interaction between students with each other and faculty members. 


\section{Limitations}

This study faced many difficulties; as it was planned to carry out this study in more than one Arab country, but it turns out that there is a scarcity of the faculty members in many Arab countries, especially countries that have only one department or program for social work in one university such as Kuwait and the Sultanate Oman, these countries have a small number of faculty members in social work, which would not give indications. Therefore they were excluded, and only Egypt, Saudi Arabia, and Jordan were left, The second difficulty lies in the scarcity of Arab research and studies, in general, that deal with distance social work education and the scarcity of research and studies that dealt with distance education in the social sciences and human professions in general in the Arab world. The researcher also made a great effort in telephone and electronic communication with some heads of departments and coordinators of social work programs in the three countries to urge them to participate in the study, and this matter took more time and effort.

\section{Implications for research}

The current study monitored the reality of distance social work education in the Arab world from faculty members' perspectives. For the picture to be clearer there is a need for a parallel study that seeks the same goal, but from the students' perspective. The researcher also recommends conducting a comparative study that demonstrates the efficiency of traditional and distance social work education by applying to students who received both types of education.

\section{Conclusion}

According to this study's results, the distance social work education system does not enjoy the support and acceptance of faculty members in the Arab world. After using this system in light of the current Coronavirus (COVID-19) crisis, most of them agree that its defects outweigh its advantages, and it is inconsistent with the special - human interactive nature of the social work profession. This system faces many obstacles, 
perhaps the most prominent of which is, for example, but not limited to, the inability to implement field training plans and the lack of direct interaction between students that supports their human experiences. These constraints naturally affect this system's efficiency and limit its ability to achieve the required objectives and desired social work education results. This places this educational process in real danger and threat in the continuation of the Coronavirus (COVID-19) pandemic and the need to adopt this system in the coming years. 


\section{References}

[1] Abd El -Aziz, A \& Muhammad, A. (2012) Obstacles to e-learning from the viewpoint of female students at the College of Education for Girls in Babha, Journal of the Educational Association for Social Studies: 222-256.

[2] Abu Al-Nasr, Medhat (2017). Distance Training is your Way to a Better Future, Cairo, Egyptian Books House.

[3] Ali, W. (2020). Online and Remote Learning in Higher Education Institutes: A Necessity in light of COVID-19 Pandemic. Higher Education, 10(3): 16-25.

[4] Al-Muhaisen, I. (2003) E-learning ... luxury or necessity ...? A working paper presented to a school seminar. August 16-17 p. 46- 48 King Saud University, Saudi Arabia.

[5] Al - Naggar, Atef (2019). Determinants of distance social work education from the perspective of general practice in social service. Journal of the Faculty of Social Work for Social Studies and Research, Fayoum University, (15), 686-716.

[6] Al-Qahtani, Mohammed (2010). Impact of Using Social Programming on Electronic Practice Competences Among faculty members at University of King Khaled, Ph.D dissertation, Faculty of Education, University of Om Al Qura.

[7] Al-Shaboul, Muhannad (2014): faculty members' attitudes at Jordanian Universities towards Distance Education and its relation to some Variables, Unpublished Master's dissertation, Postgraduate Studies Faculty, Jordanian Universities.

[8] Al - Shahri ,Sami (2019). faculty members' attitudes at University of King Khaled towards Using Electronic Education in Math Teaching, Specialist Educational Journal, 8(6):1-13

[9] Al-Sharhan, S (2014) Open Education and Distance Education in the Arab World: Towards Development and Creativity, Conference: ALECSO - League of Arab States - Congress of Ministers of Higher Education and Scientific Research in the Arab World At: Riyadh, KSA, V (1): 38-65

[10] Al-Talani ,Nedhal (2012). faculty members' attitudes at Applied Al Balkaa University towards Using Electronic Education in College Teaching, Ain Shams University, Knowledge and Reading Journal, v (122): $106-152$.

[11] Baez, J. C., Marquart, M., Chung, R. Y. E., Ryan, D., \& Garay, K. (2019). Developing and Supporting Faculty Training for Online Social Work Education: The Columbia University School of Social 
Work Online Pedagogy Institute. Journal of Teaching in Social Work, 39 (4-5):505-518.

[12] Barakat, Z (2012). Difficulties in Using the Internet for Al-Quds Open University Students in Tulkarm, Journal of the Islamic University for Educational and Psychological Studies 20 (1): 521-556.

[13] Burgess, S., \& Sievertsen, H. H. (2020). Schools, skills, and learning: The impact of COVID-19 on education. Vox Eu.org, 1.

[14] Collins, S. (2008). Open and distance learning in qualifying social work education in Britain and the USA: celebrating diversity and difference?. Social Work Education, 27(4):422-439.

[15] Crisp, B. (2018) From distance to online education: two decades of remaining responsive by one university social work programme, Social Work Education 37(6): 718-730

[16] CSWE (2020). Covid-19 and Social Work Education: https: //www.cswe.org/About-CSWE/Responding-to-Coronavirus

[17] Davis, C., Greenaway, R., Moore, M., \& Cooper, L. (2019). Online teaching in social work education: Understanding the challenges. Australian Social Work, 72(1), 34-46.

[18] Demirbilek, M. (2019).Distance Education - A Means to Equal Opportunities in Education: Case Study of Ankara University, Department of Social Work :in Krystev. V., Efe. R., and Atasot, E: Theory and Practice in Social Sciences , St. Kliment Ohridski University Press

[19] Dinh, L. \& Nguyen, T.(2020) Pandemic, social distancing, and social work education: students' satisfaction with online education in Vietnam,, Social Work Education 39(8): 1074-1083

[20] Dominelli, L., Harrikari, T., Mooney, J., Leskošek, V and Tsunoda, E.K. (2020). Covid-19 and social work: A Collection of Country Reports, Contributors are members of the COVID-19 Social Work Research Forum , IASSW

[21] East, J., LaMendola, W., \& Alter, C. (2014) Distance Education and Organizational Environment', Journal of Social Work Education 50(1): 19-33.

[22] Jemni, M., \& Khribi, M. K. (2017). Toward empowering open and online education in the Arab world through OER and MOOCs. In Open education: from OERs to MOOCs (pp. 73-100). Springer, Berlin, Heidelberg.

[23] Kourgiantakis, T, and Eunjung L. (2020). Social work practice education and training during the pandemic: Disruptions and discoveries." International Social Work 63(6):761-765 
[24] Kurzman, P. (2019). The Current Status of Social Work Online and Distance Education. Journal of Teaching in Social Work, 39(4-5): 286-292.

[25] Kurzman, P.\& Littlefield M. (2020) Online and Distance Social Work Education Current Practice and Future Trends, London. Routledge Taylor \& Francis Group

[26] Levin, S., Fulginiti, A., Moore, B. (2018). The Perceived Effectiveness of Online Social Work Education: Insights from a National Survey of Social Work Educators', Social Work Education 37(6): 775-789

[27] Moore, B. (2008). Using technology to promote communities of practice $(\mathrm{CoP})$ in social work education. Social Work Education, 27(6): 592-600.

[28] Oliaro, L. \& Trotter, C. (2010).A Comparison of On-Campus and OffCampus (or Distance) Social Work Education, Australian Social Work 63(3): 329-344

[29] Reamer, F. G. (2013). Distance and online social work education: Novel ethical challenges. Journal of Teaching in Social Work, 33(4-5), 369384.

[30] Reamer, F. G. (2019). Social work education in a digital world: Technology standards for education and practice. Journal of Social Work Education, 55(3): 420-432.

[31] Sayed, Gomana (2020). Social Work Students Attitudes towards Using Technology in Social Work Education in the light of COVID-19 Pandemic, Social Work Faculty Journal for Social Studies, Al Fayoum University, 21 (4):353-381.

[32] Secret, M., Bentley, K. J., \& Kadolph, J. C. (2016). Student voices speak quality assurance: Continual improvement in online social work education. Journal of Social Work Education, 52(1): 30-42.

[33] Singh, R. (2016) Experiences of Canadian distance education social work students with mental health (dis)abilities, Master's Thesis, Dalhousie University, Halifax, Canada.

[34] Slanetz, P. J., Parikh, U., Chapman, T., \& Motuzas, C. L. (2020). Coronavirus Disease 2019 (COVID-19) and Radiology EducationStrategies for Survival. Journal of the American College of Radiology, 17(6): 743-745

[35] Smith, K., Jeffery, D. \& Collins, K.(2018).Slowing things down: taming time in the neoliberal university using social work distance education, social work education 37(6): 691-704

[36] Smoyer, A. B., O’Brien, K., \& Rodriguez-Keyes, E. (2020). Lessons learned from COVID-19: Being known in online social work classrooms. International Social Work, 1-4. 
[37] Szilagyi, L., Munoz, D. \& Diaconu, M.(2013). Challenges and opportunities to eLearning in social work education: perspectives from Spain and the United States, European Journal of Social Work 21(6):836-849

[38] Tedam, P. (2020). Social distancing and social work field placements. The Journal of Practice Teaching and Learning, 17(1): 51-56.

[39] Tlili, A., Jemni, M., Khribi, M. K., Huang, R., Chang, T. W., \& Liu, D. (2020). Current state of open educational resources in the Arab region: an investigation in 22 countries. Smart Learning Environments v (7) $: 1-15$.

[40] Tuncay, T. (2020). Online Social Work Education: Opportunities and Obstacles, Turkish Journal of Social Work Research, 4(1): 18-25

[41] York, R. O. (2008). Comparing three modes of instruction in a graduate social work program. Journal of Social Work Education, 44(2):157172

[42] Vernon, R., Vakalahi, H., Pierce, D., Pittman-Munke, P., \& Adkins, L. F. (2009). Distance education programs in social work: Current and emerging trends. Journal of Social Work Education, 45(2): 263-276.

[43] Zidan, T. (2015). Teaching social work in an online environment. Journal of Human Behavior in the Social Environment, 25(3): 228-235. 